\title{
Severe Acute Respiratory Syndrome Coronavirus 2 Host Cell Entry Might Involve Beta Adrenergic Receptors
}

\author{
Natesan Vasanthakumar*
}

\author{
Natesan Vasanthakumar* \\ Abel Clinic, Uthangarai, Krishnagiri, \\ Tamil Nadu. INDIA. \\ *Correspondence \\ Dr. Natesan Vasanthakumar \\ Abel Clinic, Uthangarai, \\ Krishnagiri-635207, Tamil Nadu. INDIA. \\ Phone: +916380831065 \\ Email: vasanth.dr@gmail.com \\ History \\ - Submission Date: 11-07-2020; \\ - Review completed: 20-08-2020; \\ - Accepted Date: 03-09-2020. \\ DOI : 10.5530/ijcep.2020.7.3.30 \\ Copyright \\ (C) 2020 Phcog.Net. This is an open- \\ access article distributed under the terms \\ of the Creative Commons Attribution 4.0 \\ International license.
}

Sir,

Coronavirus disease 2019 (COVID-19) is caused by Severe acute respiratory syndrome coronavirus 2 (SARS-CoV-2) infection. SARS-CoV-2 enters the host cell by binding its spike protein with the angiotensin converting enzyme 2 (ACE2) receptor Cluster of differentiation 147 (CD147) also known as Basigin or extracellular matrix metalloproteinase inducer (EMMPRIN), has been proposed as another host cell receptor that might be involved in SARSCoV-2 cellular entry. ${ }^{[1]}$ Any other host cell receptors that exist for SARS-CoV-2 is not known at present.

SARS-CoV-2 shares high similarity with SARS-CoV is well known. For SARS-CoV, it has been already shown that along with the ACE2 receptor in the host cell, surface vimentin by its association with ACE2 acts as a co-receptor for SARS-CoV cellular entry. ${ }^{[2]}$ For SARS-CoV-2 also surface vimentin might act as co-receptor. Drugs targeting vimentin has been proposed as a treatment for COVID-19. ${ }^{[3]}$ It is interesting to note that vimentin is involved in beta adrenergic receptor activation and regulates the extracellular signal-regulated kinase (ERK) pathway. ${ }^{[4]}$ Beta adrenergic receptor via vimentin may be associated with the ACE2 receptor and involved in SARS-CoV-2 host cell entry.

As mentioned earlier CD147 might be another host cell receptor involved in SARS-CoV-2 cellular entry. It is known that CD147 forms complex with beta2 adrenergic receptors and this complex plays a crucial role in meningococcal infection. ${ }^{[5]} \mathrm{A}$ similar process of CD147 forming complex with beta adrenergic receptor might happen in SARS-CoV-2 infection also. I suggest that the Beta adrenergic receptor might be involved in the SARS-CoV-2 cell entry, by its interaction via surface vimentin to the ACE2 receptor and by forming a complex with CD147. It is interesting to note that beta blockers have been already proposed as a treatment option for COVID-19. ${ }^{[6]}$ Whether beta-adrenergic receptors act as a co-receptor for SARS-CoV-2 cell entry needs to be found experimentally in the future.

\section{CONFLICT OF INTEREST}

Author declare that they have no conflict of interest.

\section{Funding}

The author did not receive any funding.

\section{REFERENCES}

1. Wang K, Chen W, Zhou YS, Lian JQ, Zhang Z, Du P, et al. SARS-CoV-2 Invades Host Cells Via a Novel Route: CD147-Spike Protein. BioRxiv. 2020.

2. Yu YT, Chien SC, Chen IY, Lai CT, Tsay YG, Chang SC, et al. Surface Vimentin is Critical for the Cell Entry of SARSCoV. J Biomed Sci. 2016;23:14

3. Ramos I, Stamatakis K, Oeste CL, Pérez-Sala D. Vimentin as a Multifaceted Player and Potential Therapeutic Target in Viral Infections. Preprints. 2020;2020050041.

4. Kumar N, Robidoux J, Daniel KW, Guzman G, Floering LM, Collins S. Requirement of Vimentin Filament Assembly for $\beta$-Adrenergic Receptor Activation of ERK MAP Kinase and Lipolysis. J Biol Chem. 2007;282(12):9244-50.

5. Maïssa N, Covarelli $V$, Janel S, Durel B, Simpson N, Bernard SC, et al. Strength of Neisseria Meningitidis Binding to Endothelial Cells Requires Highly-Ordered CD147/ $\beta_{2}$-Adrenoceptor Clusters Assembled by AlphaActinin-4. Nat Commun. 2017;8(1):1-5

6. Vasanthakumar N. Can Beta-Adrenergic Blockers be used in the Treatment of COVID-19?. Med Hypotheses. 2020;142:109809.

Cite this article: Vasanthakumar N. Severe Acute Respiratory Syndrome Coronavirus 2 Host Cell Entry Might Involve Beta Adrenergic Receptors. Int J Clin Exp Physiol. 2020;7(3):125. 